\title{
Entrevista com Prof. Dr. Hu Xudong 胡续冬
}

\author{
Mariana Hase Ueta ${ }^{1}$
}

\begin{abstract}
O Professor Doutor Hu Xudong é pesquisador no Núcleo de Cultura Brasileira da Universidade de Pequim e Professor do Instituto de Literatura Mundial da mesma universidade. Ele é considerado também um dos dez mais importantes novos poetas da China e recebeu o prêmio Rougang Poetry Award (2003) e o Liu Li'an Award (1998). Desde o início dos seus estudos sobre o Brasil, $\mathrm{Hu}$ tem sido um forte incentivador da parceria acadêmica sinobrasileira e uma importante referência para todos os envolvidos na área.
\end{abstract}

Revista Idéias: Como você se interessou em estudar o Brasil? Como foi a sua trajetória pessoal e profissional?

Hu Xudong: Eu me interessei nos estudos sobre o Brasil por coincidência. No ano 2003, através de um contrato de intercâmbio de professores, a minha universidade, Universidade de Pequim, ficou encarregada de mandar um professor para a UnB. Coincidentemente este cargo foi delegado a mim, um professor jovem e sem falar nenhuma palavra em português. Fiquei na UnB por um ano e alguns meses ensinando língua e cultura chinesa, ao mesmo tempo, consegui aprender português na convivência com os brasileiros, me apaixonei pela cultura brasileira e comecei a fazer alguns pequenos estudos sobre o Brasil.

${ }^{1}$ Cientista Social, doutoranda em Ciências Sociais e membro da equipe editorial da Idéias. 
Me formei em literatura chinesa contemporânea e literatura comparada, e no ano 2002 me tornei um professor de literatura mundial no Instituto de Literatura Mundial da Escola de Línguas Estrangeiras na Universidade de Pequim, mesma universidade onde conclui a graduação, mestrado e doutorado. Além da vida acadêmica, sou também poeta e crítico literário. Depois de voltar do Brasil no ano 2005, fui nomeado vice-diretor do Núcleo da Cultura Brasileira na minha universidade, inevitavelmente tomei literatura e cultura brasileira como uma parte da minha pesquisa na área de literatura comparada. Na minha carreira literária, assumi outra função, tradutor de poesia brasileira. Publiquei traduções de Carlos Drummond de Andrade e João Cabral de Melo Neto na China. Ainda passei por outra mudança interessante. Antigamente, na escrita criativa, eu só escrevia poesia, mas quando eu estava no Brasil, escrevi cada dia um ensaio sobre as minhas experiências no país. Depois de voltar a Pequim, estes ensaios já formavam um livro grosso. Daí me tornei também um ensaísta, publiquei vários livros de ensaio, incluindo aquele livro sobre as minhas experiências no Brasil que foi bem recebido pelo público e um sucesso de vendas.

Revista Idéias: De que forma se transformaram os estudos sobre o Brasil na China desde que você iniciou suas pesquisas?

Hu Xudong: Na China já existia uma tradição de estudos do Brasil a partir da época de Mao. Dentro da estrutura dos estudos da América Latina, estas pesquisas se concentravam mais na área de política, relações internacionais e economia. Na minha área, literatura, a pesquisa da literatura brasileira também se integrava à pesquisa da literatura latino-americana, onde a história da literatura brasileira sempre era vista como um capítulo da história literária da América Latina. Durante estes últimos 15 anos, os estudos sobre o Brasil se desenvolveram muito rápido. Além de pesquisas nas áreas de política, relações internacionais, economia, agora temos pesquisadores que se dedicam a história, literatura, cinema, antropologia, sociologia, história da arte, etc. Temos um Núcleo da Cultura Brasileira na Universidade de Pequim, um 
Centro do Estudo Brasileiro na CASS (Chinese Academy of Social Sciences), e ainda temos muitas divisões de estudos brasileiros em vários institutos de pesquisas sobre BRICS ou América Latina por toda a China. Na minha área de literatura, os tradutores e pesquisadores da literatura brasileira são quase 10 vezes mais numerosos do que antes, e foram reponsáveis por fazer da história literária brasileira uma obra por si só, independente da história literária latino-americana. Alguns pesquisadores iniciaram debates na mídia destacando a importância de separar a narrativa sobre o Brasil das suas demais formas latino-americanas.

Revista Idéias: Qual é o maior interesse dos alunos chineses na área de estudos brasileiros?

Hu Xudong: Depende. Os alunos das Humanidades sempre querem saber como se construiu a Brasilidade que é reflexo de tanta diversidade cultural num só pais. Os alunos das Ciências Naturais se interessam mais pelo meio ambiente do Brasil, ou a aplicação das energias novas no país.

Revista Idéias: Qualéomaior desafio para odesenvolvimento da área de estudos brasileiros na China? Qual é sua expectativa para o futuro desta área de estudos?

Hu Xudong: Acho que o maior desfio para o desenvolvimento da área de estudos brasileiros na China ainda é a falta de recursos. Não temos materiais de ensino e pesquisa suficientes, os textos acadêmicos que temos acesso agora podem já estar ultrapassados no Brasil. Não possuímos financiamento suficiente para permitir que viajemos para o Brasil, ou seja, ainda existem muitos alunos nesta área que ainda não tiveram a oportunidade de conhecer o Brasil pessoalmente. $\mathrm{O}$ custo de uma viagem entre a China e o Brasil realmente é muito caro.

A minha expectativa é que daqui a poucos anos se estabeleçam formas de intercâmbio acadêmico em diferentes níveis, sob estruturas nacionais, estatuais, municipais e particulares, 
aproveitando todos os tipos de recursos relacionados aos estudos brasileiros. Também espero que os estudos brasileiros ganhem mais espaço no debate público, e que desta forma não sejam mais considerados como estudos desconhecidos sobre coisinhas pequenininhas.

Revista Idéias: $\mathrm{O}$ que você pensa sobre o esforço brasileiro em estudar a China? Quais novos temas você acha importantes?

Hu Xudong: Tenho alguns amigos brasileiros que estudam a China, eles são muito inteligentes e qualificados, respeito todos os seus trabalhos, eles sempre me fazem observar meu próprio pais de um jeito que eu nunca tinha pensado. A sinologia ou estudo chinês no Brasil realmente não possui uma longa tradição, não é tão forte como a da Europa e dos Estados Unidos, mas hoje esta área já está bastante desenvolvida. Os sinólogos que eu conheço são de várias sub-áreas, eles desenvolvem excelentes pesquisas em linguística, literatura, cinema, sociologia, história, filosofia, administração, etc. É uma grande pena que no ano passado, uma grande sinóloga, tradutora e pesquisadora, ainda muito jovem, Profa. Márcia Schmaltz faleceu por causa do câncer. A perda da Márcia Schmaltz é imensurável. Mas os estudos dos demais pesquisadores no país darão continuidade ao seu legado.

Algumas pesquisas sobre a China realizadas por brasileiros são avançadas em comparação com os seus pares ao redor do mundo, por exemplo, estudo das escritas da viagem à América Latina do poeta Ai Qing (Prof. Francisco Foot Hardman, UNICAMP), estudo da sociologia da juventude da China (Prof. Tom Dwyer, UNICAMP), estudo dos filmes chineses contemporâneos (Profa. Cecília Melo, USP), etc.

Para falar a verdade, eu não sei quais temas são importantes para a necessidade acadêmica brasileira, pessoalmente, como um chinês, acho que tais temas são muito atrativos: o que acontecerá quando a China diminuir a velocidade de desenvolvimento econômico? Quais conexões históricas entre a China e o Brasil ainda estão escondidas e valem a pena serem investigadas? Que 
experiências incomensuráveis são responsáveis pelo processo de construção da Modernidade e Contemporaneidade na China?

Revista Idéias: Outras considerações

Hu Xudong: Visitei a Unicamp duas vezes, mas ambas as ocasiões foram tão curtas, só algumas horas. Queria muito ficar na UNICAMP por mais tempo para conhecer mais alunos e professores maravilhosos desta universidade. 
